Egyptian Journal of Rabbit Science, 27 (2): 413-- 426(2017)

\title{
IMPROVEMENT OF REPRODUCTIVE EFFECIENCY BY ADENOSINE INJECTION IN MALE RABBITS
}

\author{
M.F. Saad ${ }^{1}$, Z.I.Attia ${ }^{2}$ and T.A.EL-Sayed ${ }^{3}$ \\ ${ }^{1}$ Department of Animal Biotechnology, Animal Production Research \\ Institute, Dokki, Giza, Egypt. \\ ${ }^{2}$ Department of Zoology, Faculty of Science, Tanta University, Egypt . \\ ${ }^{3}$ Department of Zoology, Faculty of Science, Kafr El-shiekh University, \\ Egypt. $\quad$ Corresponding author (Mohamedsfahmy@yahoo.com)
}

This study was designed to evaluate mature New-Zealand White (NZW)male rabbits physiological and reproductively as affected by different levels of adenosine as growth hormone on reproductive functions of male rabbits. Eighteen white New Zealand mature male rabbits aged 56 months and weighing (2.7-2.9 kg) were divided into three groups (6 rabbits each). First group of rabbits served as a control group, second and third rabbit groups were injected intravenously by $(0.4$ and $0.8 \mathrm{mg}$ of adenosinel animal/48hours) respectively, dissolved in $0.5 \mathrm{ml}(0.9 \mathrm{NaCl})$ for 60 days. Blood samples were taken once to evaluate blood components and semen was collected twice to evaluate physical semen characteristics from each animal every 10 days.

Best results were recorded in the second group of animals (injected with $0.4 \mathrm{mg}$ adenosine/animal/48 hours), where the mean was $(7.8 \mathrm{gm} / \mathrm{dL})$ for total serum protein, $(14.5 \mathrm{gm} / \mathrm{dL})$ for hemoglobin, $(9.8 \mathrm{gm} / \mathrm{dL})$ for calcium concentration and $(7.05 \mathrm{nmol} / \mathrm{L})$ for testosterone hormone level that increased significantly $(P<0.05)$ compared to other groups at the end of the experiment. Also, the results the second group animals presented (0.97 ml ) for semen ejaculating volume, (85\%) for sperm motility, (91.8\%) for sperm live that significantly increased at $(P<0.05)$ compared to other groups and showed a significant reduction of (6\%) for sperm abnormalities than those found in other groups of animals at 60 days of experimental time.

Conclusively, this study shows that the injection by $0.4 \mathrm{mg}$ adenosine/animal every 48 hours for 60 days continuously improved physical semen characteristics, blood components and can safely be used on rabbit males.

Keywords: Adenosine, blood components, semen quality, male rabbits. 
Rabbits are domestic animals with a high economic value for both the producer and the consumer (Okpanachi et al., 2010). Rabbits' meats are low in fat, succulent, nicely flavored and provide a palatable change to chicken and other meats and also, rabbit meat plays an important role in preventing vascular disease due to its extremely low cholesterol and sodium levels (Aduku et al., 1990).

On the other hand, productivity is the key to growth and reproduction is backbone of animal production. Reproductive inefficiency is one of the most important causes of economic losses in animal industries. (Verma et al., 2012).

The quality of semen is an indicator of male fertility and can be determined by semen volume, PH, sperm concentration (sperm count), sperm viability, sperm vigor (sperm motility), normal sperm morphology and acrosome integrity (Ali and Mervat, 2013). Spermatogenesis begins between days 40 and 50, the testicular tubes become active at about 84 days and the first spermatozoa are present in the ejaculate at about 120 days of age (Lebas, 1997). Male infertility may be caused by disorders in sperm production, epididymal maturation, sperm transport and accessory sex gland function. However, sperm abnormalities are considered the main reason of male infertility as sperm production and maturation are critical indicators of male reproductive ability (Zhang et al., 2014).

Mahmoud et al., (2013), reported that Sperm motility is correlated with sperm abnormalities and membrane integrity. Live sperm percentage is the only parameter correlated with fertility. Motility and live sperm percentage could be used as a predicative measure for fertility in semen analysis of farm animals.

Adenosine is an endogenous agonist of the ghrelin/growth hormone secretagogue receptor (Claude et al., 2012). However, while it is able to increase appetite, unlike other agonists of this receptor, adenosine is unable to induce the secretion of growth hormone and increase its plasma levels which involved in all aspects of biosynthesis in cells and acts as the primary intracellular energy source. Extracellular ATP and its metabolites are involved in regulating a variety of biological processes including increasing total protein and hemoglobin concentration by the ability of globulin to transmit iron to hemoglobin (Linden, 2005 and Fredholm, 2007), also involved in liver glycogen metabolism, muscle contraction, blood flow, glycolysis and/or oxidative phosphorylation in order to increase the sperm motility and viability (Agteresch et al., 1999, Rodriguez-Miranda et al., 2008,du Plessis et al., 2015). 
Increasing the level of adenosine leads to a large increase in $\left[\mathrm{Ca}^{2+}\right]$ in all cells (Katoh, et al., 2001). Adenosine was introduced as a potent activator of sperm motility and fertilizing ability (Thuwanut et al., 2015).

Therefore, the aim of the present work was to improve rabbit's reproductive performance by enhancing the fertility of males especially during summer season by adenosine treatment.

\section{MATERIALS AND METHODS}

\section{Experimental work:}

A total of 18 New Zealand White (NZW) rabbit males were used in this study. All males were about 5-6 months of age and weighed between $2.7-2.9 \mathrm{~kg}$. Animals were kept in individual cages provided with galvanized feeders and automatic drinkers. All animals were fed ad-libitum on pelleted ration containing $17.3 \%$ crude protein, $13.5 \%$ crude fiber and $3.5 \%$ fat. Clean water was available at all times. Animals were divided into three experimental groups, each of 6 males. The first group was not injected (served as the control group), the second $(0.4 \mathrm{mg})$ and third $(0.8 \mathrm{mg})$ groups of animals were injected intravenously in ear vein with adenosine per animal every 48 hours. Adenosine powder was dissolved in $0.5 \mathrm{ml}(0.9$ $\mathrm{NaCl}$ ), the experiment lasted two months (Pagat et al., 1964).

\section{Serum biochemical examination:}

Blood samples were collected from each group every 10 days along the experimental period. At each time $3 \mathrm{ml}$ were drained and divided into two tubes, the first tube was used to obtain serum, according to Feldman et $a l$. , (2000). Clear serum was separated to be used for estimation of total protein (TP) according to Sonnenwrith and Jarette (1990).Calcium concentration was determined using a commercial kits based on spectrum diagnostic according to the principle of (Kessler and Wolfman, 1964), while enzyme immuneassay (EIA) kit (immunometrics, UK) was utilized for the testosterone assay following the technique that was earlier described (Olayemi, 2007). Liver function enzyme Aspartate aminotransferase (AST) concentration was determined by using a commercial kits according to the recommendations of expert panel of the IFCC (International Federation of Clinical Chemistry). The second tube, containing EDTA as anticoagulant was used for Hemoglobin $(\mathrm{Hb})$ concentration, determination by using commercial kits by (Hsia, 1998). 


\section{Semen collection:}

Semen samples were collected from each group after ten days of treatment and every 10 days, till the end of the experiment with a rabbit artificial vagina, (two ejaculates per male, twice every 10 days) using thermal and mechanical stimulation to stimulate ejaculation. Procedure of the collection was performed according to (Naughton et al., 2003).Physical semen characteristics as semen volume, sperm motility, sperm live and sperm abnormality were assessed for the semen sample, similarly to those described by (Essig et al., 2007 and Quinteiro et al., 2007).

\section{Statistical analysis:}

Analyses of variance (ANOVA) were carried out using the SAS software package (1996) Duncan's multiple range test was used to compare mean value of individual treatments, where the F-value was considered as significant at $(\mathrm{P}<0.05)$. The following model was used for the ANOVA:

$$
Y_{i j}=U+S_{i}+e_{i j}
$$

Where: $Y_{i j}$ is the observation on Animal $\mathrm{j}$ in the treatment $\mathrm{i} ; \mathrm{i}=1$ to 3 , $\mathrm{U}$ is the overall mean, $S_{i}$ is the effect of the treatment $i$ and $e_{i j}$ is the random error.

The differences between treatment means were separated using Duncan's new multiple range test (Duncan, 1955)at a probability level of 0.05 .

\section{RESULTS AND DISCUSSION}

In mammals, the spermatogenesis is affected by many environmental factors (temperature, light, age of animals, feeding strategies, health status and ......etc.).

Optimal conditions of rearing rabbit bucks can improve the quality of semen permitting the production of additional doses with higher and more stable fertilizing ability.

In this work, male rabbits were divided into three groups according to treatment of adenosine level.

Data analysis (Table 1) reveal, the effect of adenosine injection during two months on serum total protein, hemoglobin and calcium concentration of the three groups of male rabbits.

Form our data we observed that, the total serum protein concentration was increased gradually in all groups till the end of the experimental period, while the $2^{\text {nd }}$ group recorded significant increase $(\mathrm{P}<0.05)(7.8 \mathrm{gm} / \mathrm{dL})$ compared to the $1^{\text {st }}(6.1 \mathrm{gm} / \mathrm{dL})$ and $3^{\text {rd }}$ groups $(6.6 \mathrm{gm} / \mathrm{dL})$. Adenosine activated protein kinase, which is $\mathrm{s}$ witched on by cellular stresses that 
Table 1: Effect of adenosine injection during two months on serum total protein, hemoglobin $(\mathrm{gm} / \mathrm{dL})$ and calcium concentration $(\mathrm{mg} / \mathrm{dL})$ of male rabbits (6 months age ).

\begin{tabular}{|c|c|c|c|c|c|c|c|}
\hline Items & Groups & 10 days & 20 days & 30 days & 40 days & 50 days & 60 days \\
\hline \multirow{3}{*}{$\begin{array}{c}\text { Serum total } \\
\text { protein } \\
(\mathrm{gm} / \mathbf{d L})\end{array}$} & G1 & $\begin{array}{c}4.60 \\
\pm 0.09\end{array}$ & $\begin{array}{c}4.70 \\
\pm 0.10^{\mathrm{b}}\end{array}$ & $\begin{array}{c}4.80 \\
\pm 0.05^{\mathrm{c}}\end{array}$ & $\begin{array}{c}5.20 \\
\pm 0.06^{\mathrm{c}}\end{array}$ & $\begin{array}{c}5.40 \\
\pm 0.06^{\mathrm{c}}\end{array}$ & $\begin{array}{c}6.10 \\
\pm 0.02^{\mathrm{c}}\end{array}$ \\
\hline & G2 & $\begin{array}{c}4.80 \\
\pm 0.09\end{array}$ & $\begin{array}{c}5.10 \\
\pm 0.10^{\mathrm{a}}\end{array}$ & $\begin{array}{c}5.50 \\
\pm 0.05^{\mathrm{a}}\end{array}$ & $\begin{array}{c}6.10 \\
\pm 0.06^{\mathrm{a}}\end{array}$ & $\begin{array}{c}6.90 \\
\pm 0.06^{\mathrm{a}}\end{array}$ & $\begin{array}{c}7.80 \\
\pm 0.02^{\mathrm{a}}\end{array}$ \\
\hline & G3 & $\begin{array}{c}4.70 \\
\pm 0.09\end{array}$ & $\begin{array}{c}4.80 \\
\pm 0.10^{\mathrm{ab}}\end{array}$ & $\begin{array}{c}5.30 \\
\pm 0.05^{\mathrm{b}}\end{array}$ & $\begin{array}{c}5.60 \\
\pm 0.06^{\mathrm{b}}\end{array}$ & $\begin{array}{c}6.20 \\
\pm 0.06^{\mathrm{b}}\end{array}$ & $\begin{array}{c}6.60 \\
\pm 0.02^{\mathrm{c}}\end{array}$ \\
\hline \multirow{3}{*}{$\begin{array}{l}\text { Hemoglobin } \\
\text { (gm/dL) }\end{array}$} & G1 & $\begin{array}{c}8.16 \\
\pm 0.13 \\
\end{array}$ & $\begin{array}{c}8.50 \\
\pm 0.18 \\
\end{array}$ & $\begin{array}{c}8.50 \\
\pm 0.19^{b}\end{array}$ & $\begin{array}{r}10.00 \\
\pm 0.29^{\mathrm{c}}\end{array}$ & $\begin{array}{r}11.33 \\
\pm 0.20^{\mathrm{c}}\end{array}$ & $\begin{array}{r}11.72 \\
\pm 0.17^{\mathrm{c}}\end{array}$ \\
\hline & G2 & $\begin{array}{c}8.40 \\
\pm 0.13\end{array}$ & $\begin{array}{c}8.83 \\
\pm 0.18\end{array}$ & $\begin{array}{c}9.30 \\
\pm 0.16^{\mathrm{a}}\end{array}$ & $\begin{array}{c}13.81 \\
\pm 0.29^{\mathrm{a}}\end{array}$ & $\begin{array}{r}13.90 \\
\pm 0.20^{\mathrm{a}}\end{array}$ & $\begin{array}{r}14.50 \\
\pm 0.17^{\mathrm{a}}\end{array}$ \\
\hline & G3 & $\begin{array}{c}8.23 \\
\pm 0.13 \\
\end{array}$ & $\begin{array}{c}8.71 \\
\pm 0.18\end{array}$ & $\begin{array}{c}9.10 \\
\pm 0.16^{\mathrm{a}}\end{array}$ & $\begin{array}{r}11.33 \\
\pm 0.29^{\mathrm{b}}\end{array}$ & $\begin{array}{r}12.83 \\
\pm 0.20^{\mathrm{b}}\end{array}$ & $\begin{array}{r}12.83 \\
\pm 0.17^{\mathrm{b}}\end{array}$ \\
\hline \multirow{3}{*}{$\begin{array}{c}\text { Calcium } \\
\text { concentration } \\
(\mathbf{m g} / \mathbf{d L})\end{array}$} & G1 & $\begin{array}{c}7.30 \\
\pm 0.14\end{array}$ & $\begin{array}{c}8.60 \\
\pm 0.10\end{array}$ & $\begin{array}{c}8.63 \\
\pm 0.06\end{array}$ & $\begin{array}{c}8.91 \\
\pm 0.04^{\mathrm{b}}\end{array}$ & $\begin{array}{c}9.03 \\
\pm 0.04^{\mathrm{b}}\end{array}$ & $\begin{array}{c}9.10 \\
\pm 0.04^{\mathrm{b}}\end{array}$ \\
\hline & G2 & $\begin{array}{c}8.40 \\
\pm 0.14\end{array}$ & $\begin{array}{c}8.71 \\
\pm 0.10\end{array}$ & $\begin{array}{c}8.81 \\
\pm 0.06\end{array}$ & $\begin{array}{c}9.10 \\
\pm 0.04^{\mathrm{a}}\end{array}$ & $\begin{array}{c}9.41 \\
\pm 0.04^{\mathrm{a}}\end{array}$ & $\begin{array}{c}9.80 \\
\pm 0.04^{\mathrm{a}}\end{array}$ \\
\hline & G3 & $\begin{array}{c}8.30 \\
\pm 0.14\end{array}$ & $\begin{array}{c}8.60 \\
\pm 0.10\end{array}$ & $\begin{array}{c}8.62 \\
\pm 0.06\end{array}$ & $\begin{array}{c}9.00 \\
\pm 0.05^{\mathrm{b}}\end{array}$ & $\begin{array}{c}9.20 \\
\pm 0.04^{\mathrm{b}}\end{array}$ & $\begin{array}{c}9.50 \\
\pm 0.04^{\mathrm{b}}\end{array}$ \\
\hline
\end{tabular}

Data are expressed as Means \pm standard error $(\mathrm{X} \pm \mathrm{SE})$ using statistical significance, at $\mathrm{P}<0.05$.

$a, b, c$ In a column represented Duncan analysis of means data where ( $a>b>c)$.

$1^{\text {st }}$ group was not injected with adenosine, $2^{\text {nd }}$ group was injected with $0.4 \mathrm{mg} / \mathrm{animal} / 2$ days and the $3^{\text {rd }}$ group was injected with $0.8 \mathrm{mg} /$ animal $/ 2$ days.

interfere with ATP production, and it is responsible for regulation of cellular energy and an essential mediator of the central and peripheral effects of many hormones on the metabolism of appetite, fat and glucose. Also from above results, the total protein (albumin and globulin) helps keeping blood leaking out of the blood vessels, also carry substances through the blood and they are important for tissue growth, also globulin binds with hemoglobin and transport iron in the blood and fight infection. The increase of globulin leads to increasing the ratio of total protein. Total protein is necessary for improving the ability of rabbits to attack infections during summer seasons, increases breathing rate and improve the concentration of hemoglobin (Dhinaa and Palanisamy, 2010, Hardie, 2003 and Jayabalan et al., 2012).

Mean of hemoglobin concentration increased gradually in the three groups during experiment time. In the end of the experiment, the 
hemoglobin concentrations were $(11.72 \mathrm{gm} / \mathrm{dL}), \quad(14.50 \mathrm{gm} / \mathrm{dL})$ and $(12.83 \mathrm{gm} / \mathrm{dL})$ for the $1^{\text {st }}, 2^{\text {nd }}$ and $3^{\text {rd }}$ groups respectively. These results cleared that the second group recorded the best mean value $(14.5 \mathrm{gm} / \mathrm{dL})$ and that significantly $(\mathrm{P}<0.05)$ differed between all groups. (Yujin et al., 2010), reported that, hemoglobin concentration increased when mice were treated by adenosine and was significantly elevated in the plasma of cycle cell. Moreover, total protein lead to increase in hemoglobin concentration by the ability of globulin to transmit iron to hemoglobin and therefore increasing of hemoglobin concentration (Linden J. 2005 and Fredholm, 2007).

Result showed that, the mean serum calcium concentration $(\mathrm{mg} / \mathrm{dl})$ increased slowly to be $(9.10,9.80$ and $9.50 \mathrm{mg} / \mathrm{dL})$ for $1^{\text {st }}, 2^{\text {nd }}$ and $3^{\text {rd }}$ groups at the end of experiment respectively. The mean of the $2^{\text {nd }}$ group was the best result compared to other groups and significantly at $(\mathrm{P}<0.05)$, but the control group recorded the lowest value in serum calcium concentration. Calcium is a mineral that is an essential part of bones, teeth, nerves and blood clotting. Serum calcium concentration increased during the experimental period that agree with Kara et al., 2010.

Diagram (1), show, the effect of adenosine injection for 2 months on concentration of liver function indicator (AST) (M/L) of rabbit males(5-6 months) age for one time after ending the experiment on the three groups.

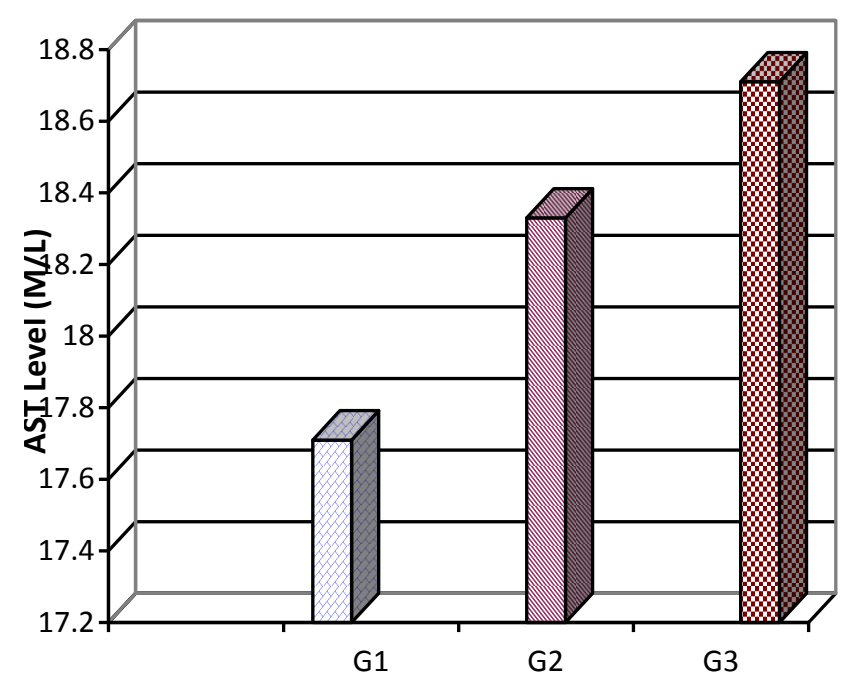

Diagram (1): Effect of adenosine injection for two months on liver function (AST) $\mathrm{M} / \mathrm{L}$ of male rabbits (6 months age). 
The results were $(17.71),(18.33)$ and $(18.71 \mathrm{M} / \mathrm{L})$ for $1^{\text {st }}, 2^{\text {nd }}$ and $3^{\text {rd }}$ groups respectively, where there was no significant difference at $(\mathrm{P}<0.05)$ between all groups. These results indicated that, adenosine is safe when it used for rabbits. Adenosine is an energy source for aspartate synthesis which is an important protein synthesis in muscle and AST enzyme is essential for glutamate and aspartate synthesized transamination (Michael, 2012).

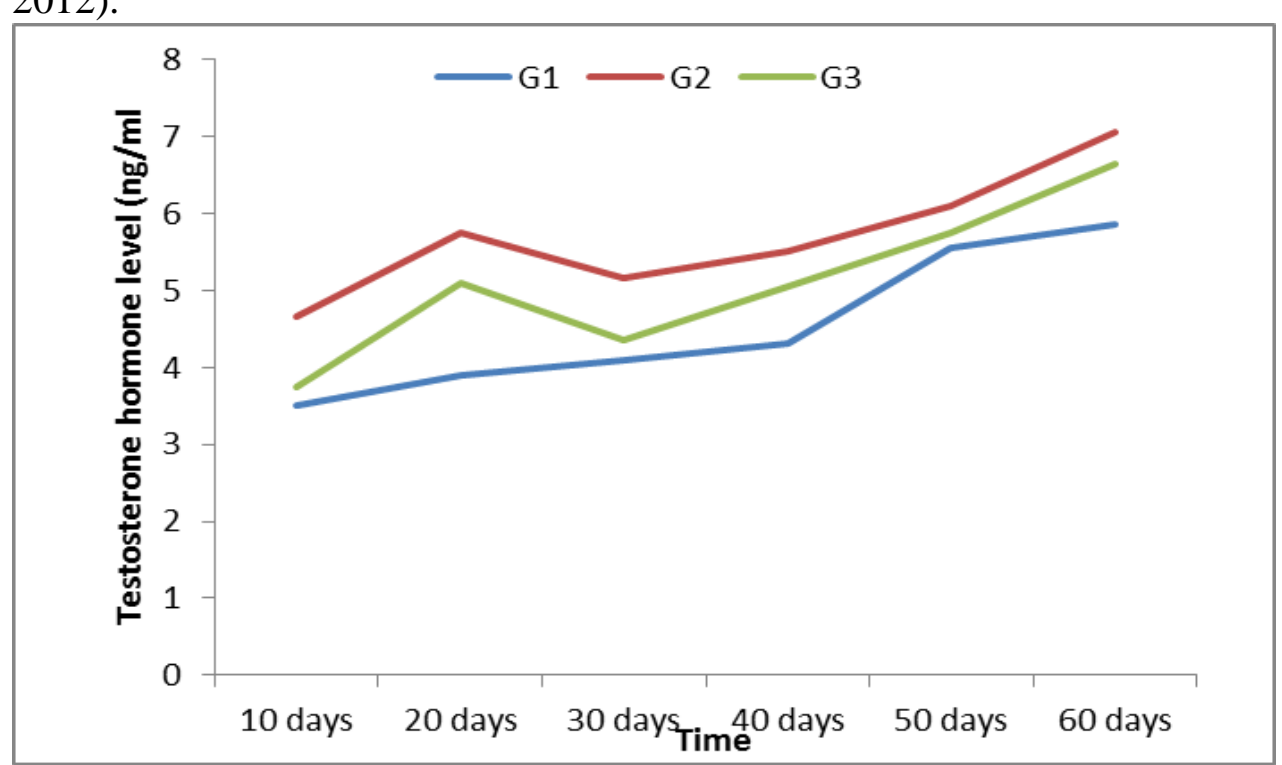

Diagram (2), explain that, the means of testosterone hormone level were $(4.3),(5.5)$ and $(5.1 \mathrm{ng} / \mathrm{ml})$ for $1^{\text {st }}, 2^{\text {nd }}$ and $3^{\text {rd }}$ groups respectively at 40 days of treatment with adenosine, these result increased slowly and nonsignificantly $(\mathrm{P}<0.05)$ between groups. But after 60 days, means of testosterone levels were (5.9), (7.1) and $(6.7 \mathrm{ng} / \mathrm{ml})$ for $1^{\text {st }}, 2^{\text {nd }}$ and $3^{\text {rd }}$ groups respectively, where there was significant difference at $(\mathrm{P}<0.05)$ between $1^{\text {st }}$ and $2^{\text {nd }}$ groups and between $1^{\text {st }}$ and $3^{\text {rd }}$ groups, but there was no significant difference between $2^{\text {nd }}$ and $3^{\text {rd }}$ groups. From the above results, the highest mean testosterone hormone level was in the $2^{\text {nd }}$ group $(7.1 \mathrm{ng} / \mathrm{ml})$. These results agree with (Ceballos et al., 1999, William and Jing, 2005 and Ammar, 2004), who reported that, testosterone hormone have a significant effect on activation of sertoli cells and germ cells to activate spermatogenesis and also, sertoli cell transduct signals from testosterone to germ cells to produce spermatozoa by acting or releasing of adenosine.

Diagram (2): Effect of adenosine injection during two months on testosterone hormone level $(\mathrm{ng} / \mathrm{ml})$ of male rabbits (6 months age ). 
Table (2) show, the effect of adenosine injection on physical characteristics of male rabbits. The means of semen volume ejaculate were increased during treatment period by adenosine $(0.81),(0.97)$ and $(0.93 \mathrm{ml})$ for $1^{\text {st }}, 2^{\text {nd }}$ and $3^{\text {rd }}$ groups after 60 days of treatment. The result was higher in the $2^{\text {nd }}$ group, that increased significantly $(\mathrm{P}<0.05)$ between $2^{\text {nd }}$ and $1^{\text {st }}$ groups but was non-significantly between $2^{\text {nd }}$ and $3^{\text {rd }}$ groups. Results showed that the highest mean of ejaculated semen volume was $(0.97 \mathrm{ml})$ in the second group at the end of the experiment (60 days). These results agree with (Gustavo et al., 2001), who reported that the increase of serum testosterone hormone level increased the secretory activity of the seminal vesicles and increased seminal vesicles weight, which is related to adenosine activity.

Adenosine stimulate spermatogenesis so it increase the concentration of seminal fluid that to increase of ejaculate semen volume. Also, Griffeth et al., (2014) reported that, ATP appears to the major intra-testicular signal controlling (SC) number, testis size and sperm output in mammals.

In the same Table (2) the percentage means of semen motility increased gradually were $(76.71 \%),(85.00 \%)$ and $(83.33 \%)$ for $1^{\text {st }}, 2^{\text {nd }}$ and $3^{\text {rd }}$ groups respectively at the experiment end. These result recorded the higher percentage in the $2^{\text {nd }}$ group and significantly $(\mathrm{P}<0.05)$ differed between $2^{\text {nd }}$ and $1^{\text {st }}$, but it was nonsignificantly different between $2^{\text {nd }}$ and $3^{\text {rd }}$ groups. These results explained that, adenosine lead to mitochondrial activity and sperm quality which agrees with (Thuwanut and Chatdarong, 2011), suggested that, the quality of cat sperm when treated with adenosine (ATP), for 10 minutes showed significant change in mitochondrial activity and sperm quality. Albarracin et al., (2004) reported that, the spermatozoa motility depends on energy supply. Both of energy metabolism in mitochondria and motility system of the cells are involved in the activation of the sperm flagellum. Percentages of live sperm were increased gradually up to $(80.47 \%),(91.80 \%)$ and $(86.71 \%)$ at the experiment end for $1^{\text {st }}, 2^{\text {nd }}$ and $3^{\text {rd }}$ group. From above results the higher percentage of live sperm was in the second group. These results were significantly different $(\mathrm{P}<0.05)$ between $2^{\text {nd }}$ and $1^{\text {st }}$ groups, while were nonsignificant between $2^{\text {nd }}$ and $3^{\text {rd }}$ groups. This results agree with (Marchetti et al., 2004; Gogol et al., 2009 and Gogol 2013), who showed that, ATP content of spermatozoa, is considered a sensitive indicator of energy metabolism, motility and sperm live and importantly, it also plays a major role in the proper development and function of the testis. 
Table 2: Effect of adenosine injection during two months on semen ejaculating volume $(\mathrm{ml})$, percentages of sperm motility, sperm live and sperm abnormalities of male rabbits ( 6 months age).

\begin{tabular}{|c|c|c|c|c|c|c|c|}
\hline Items & Groups & 10 days & 20 days & 30 days & 40days & 50 days & 60 days \\
\hline \multirow{3}{*}{$\begin{array}{c}\text { Volume } \\
\text { (ml) }\end{array}$} & G1 & $\begin{array}{c}0.50 \\
\pm 0.05\end{array}$ & $\begin{array}{c}0.60 \\
\pm 0.08\end{array}$ & $\begin{array}{c}0.71 \\
\pm 1.00\end{array}$ & $\begin{array}{c}0.68 \\
\pm 1.00\end{array}$ & $\begin{array}{c}0.81 \\
\pm 0.10\end{array}$ & $\begin{array}{c}0.81 \\
\pm 0.08^{\mathrm{b}}\end{array}$ \\
\hline & G2 & $\begin{array}{c}0.61 \\
\pm 0.05\end{array}$ & $\begin{array}{c}0.73 \\
\pm 0.08\end{array}$ & $\begin{array}{c}0.75 \\
\pm 1.00\end{array}$ & $\begin{array}{c}0.91 \\
\pm 0.06\end{array}$ & $\begin{array}{c}0.93 \\
\pm 0.08\end{array}$ & $\begin{array}{c}0.97 \\
\pm 0.08^{\mathrm{a}}\end{array}$ \\
\hline & G3 & $\begin{array}{c}0.50 \\
\pm 0.05\end{array}$ & $\begin{array}{c}0.71 \\
\pm 0.08\end{array}$ & $\begin{array}{c}0.73 \\
\pm 1.00\end{array}$ & $\begin{array}{c}0.91 \\
\pm 0.06\end{array}$ & $\begin{array}{c}0.91 \\
\pm 0.08\end{array}$ & $\begin{array}{c}0.93 \\
\pm 0.08^{\mathrm{a}}\end{array}$ \\
\hline \multirow{3}{*}{$\begin{array}{c}\text { Mot. } \\
(\%)\end{array}$} & G1 & $\begin{array}{l}66.71 \\
\pm 1.66\end{array}$ & $\begin{array}{l}63.33 \\
\pm 2.35\end{array}$ & $\begin{array}{l}68.33 \\
\pm 1.92\end{array}$ & $\begin{array}{l}71.71 \\
\pm 1.66\end{array}$ & $\begin{array}{c}81.71 \\
\pm 1.71^{\mathrm{b}}\end{array}$ & $\begin{array}{c}76.71 \\
\pm 1.36^{\mathrm{b}}\end{array}$ \\
\hline & G2 & $\begin{array}{l}68.33 \\
\pm 1.66\end{array}$ & $\begin{array}{l}68.33 \\
\pm 2.35\end{array}$ & $\begin{array}{l}70.00 \\
\pm 1.92\end{array}$ & $\begin{array}{r}78.33 \\
\pm 1.71^{\mathrm{a}}\end{array}$ & $\begin{array}{r}83.00 \\
\pm 2.71^{\mathrm{a}}\end{array}$ & $\begin{array}{r}85.00 \\
\pm 1.36^{\mathrm{a}}\end{array}$ \\
\hline & G3 & $\begin{array}{l}66.70 \\
\pm 1.66\end{array}$ & $\begin{array}{l}61.71 \\
\pm 2.35\end{array}$ & $\begin{array}{l}70.00 \\
\pm 1.92\end{array}$ & $\begin{array}{l}71.71 \\
\pm 1.71\end{array}$ & $\begin{array}{r}83.33 \\
\pm 2.72^{\text {a }}\end{array}$ & $\begin{array}{r}83.33 \\
\pm 1.66^{\mathrm{a}}\end{array}$ \\
\hline \multirow{3}{*}{$\begin{array}{l}\text { Live } \\
(\%)\end{array}$} & G1 & $\begin{array}{r}73.33 \\
\pm 1.27^{\mathrm{b}} \\
\end{array}$ & $\begin{array}{r}74.71 \\
\pm 1.52^{\mathrm{b}} \\
\end{array}$ & $\begin{array}{r}70.33 \\
\pm 1.93^{\mathrm{b}} \\
\end{array}$ & $\begin{array}{c}72.71 \\
\pm 1.59^{\mathrm{b}}\end{array}$ & $\begin{array}{c}76.71 \\
\pm 1.59^{\mathrm{b}}\end{array}$ & $\begin{array}{c}80.47 \\
\pm 2.11^{\mathrm{b}}\end{array}$ \\
\hline & G2 & $\begin{array}{c}76.71 \\
\pm 1.27^{\mathrm{a}} \\
\end{array}$ & $\begin{array}{r}82.71 \\
\pm 1.52^{\mathrm{a}} \\
\end{array}$ & $\begin{array}{r}85.00 \\
\pm 1.93^{\mathrm{a}} \\
\end{array}$ & $\begin{array}{c}81.71 \\
\pm 1.59^{\mathrm{a}} \\
\end{array}$ & $\begin{array}{r}86.71 \\
\pm 1.59^{\mathrm{a}} \\
\end{array}$ & $\begin{array}{r}91.8 \\
\pm 2.11^{\mathrm{a}} \\
\end{array}$ \\
\hline & G3 & $\begin{array}{r}75.00 \\
\pm 1.27^{\mathrm{ab}}\end{array}$ & $\begin{array}{r}79.71 \\
\pm 1.52^{\mathrm{a}}\end{array}$ & $\begin{array}{c}81.71 \\
\pm 1.93^{\mathrm{a}}\end{array}$ & $\begin{array}{r}78.33 \\
\pm 1.59^{\mathrm{a}}\end{array}$ & $\begin{array}{c}84.71 \\
\pm 1.59^{\mathrm{a}}\end{array}$ & $\begin{array}{c}86.71 \\
\pm 2.11^{\mathrm{a}} \\
\end{array}$ \\
\hline \multirow{3}{*}{$\begin{array}{c}\text { Abno.( } \\
\%)\end{array}$} & G1 & $\begin{array}{r}13.33 \\
\pm 0.57\end{array}$ & $\begin{array}{r}14.33 \\
\pm 0.33\end{array}$ & $\begin{array}{r}13.00 \\
\pm 0.67\end{array}$ & $\begin{array}{c}12.67 \\
\pm 0.33^{\mathrm{a}}\end{array}$ & $\begin{array}{l}11.00 \\
\pm 0.45^{\mathrm{a}}\end{array}$ & $\begin{array}{c}10.67 \\
\pm 0.57^{\mathrm{a}}\end{array}$ \\
\hline & G2 & $\begin{array}{l}11.00 \\
\pm 0.57\end{array}$ & $\begin{array}{l}11.67 \\
\pm 0.33\end{array}$ & $\begin{array}{r}11.33 \\
\pm 0.67\end{array}$ & $\begin{array}{c}10.67 \\
\pm 0.00^{\mathrm{b}}\end{array}$ & $\begin{array}{c}7.33 \\
\pm 0.45^{\mathrm{b}}\end{array}$ & $\begin{array}{c}6.00 \\
\pm 0.57^{\mathrm{c}}\end{array}$ \\
\hline & G3 & $\begin{array}{r}11.33 \\
\pm 0.57\end{array}$ & $\begin{array}{l}11.33 \\
\pm 0.33\end{array}$ & $\begin{array}{r}11.67 \\
\pm 0.67\end{array}$ & $\begin{array}{c}10.00 \\
\pm 0.00^{\mathrm{b}}\end{array}$ & $\begin{array}{c}6.00 \\
\pm 0.45^{\mathrm{c}}\end{array}$ & $\begin{array}{c}7.67 \\
\pm 0.57^{b}\end{array}$ \\
\hline
\end{tabular}

Data are expressed as means \pm standard error $(\mathrm{X} \pm \mathrm{SE})$ using statistical significance, at $\mathrm{P}<0.05$.

a,b,c : Within a column represented Duncan analysis of data, where $(a>b>c)$.

$1^{\text {st }}$ group was not injected by adenosine, $2^{\text {nd }}$ group was injected with $0.4 \mathrm{mg}$ of adenosine /animal and $3^{\text {rd }}$ group was injected by $0.8 \mathrm{mg}$ of adenosine/animal.

The results explained that, the percentages of sperm abnormality were $(10.67 \%),(6.00 \%)$ and $(7.67 \%)$ for $1^{\text {st }}, 2^{\text {nd }}$ and $3^{\text {rd }}$ groups respectively, the percentage of sperm abnormality in second group was less than those in other groups at experiment end. After 60 days the percentages of sperm abnormality were showing significant decreased $(\mathrm{P}<0.05)$ between all groups.

Sperm abnormalities are considered the main reason of male infertility as sperm production and maturation are critical indicators of male reproductive ability. From above results, we can expect the fertility rate in 
the rabbit production and agree with (Qunteiro et al., 2007), who developed a composite index using a multivariate regression approach by entering several parameters of rabbit semen (motility, sperm abnormalities and altered acrosomes) whish better predicts the fertilizing ability and the prolificacy of semen samples.

Conclusively, the best results in terms of increasing the quality of physical semen characteristics and enhancing the fertility parameters of male rabbits (especially during high temperature in summer season) can be fulfilled using adenosine injection ( $0.4 \mathrm{mg} /$ adenosine/2days), which proved to be safe and economically feasible in rabbit industry.

\section{RFERENCES:}

Aduku A.O. and Olukosi J.O. (1990). Rabbit Management in the Tropics.Living Book Series. G. U. Puplications, Abuja, Nigeria. 5-20.

Agteresch H.J., Dagnelie P.C., van den Berg J.W. and Wilson J.H.(1999). Adenosine triphosphate:established and potential clinical applications. Drugs, 58 (2):211-232.

Albarracin J.L., Mogas T., Paloma M.J., Peña A., Rigua T. and Rodriguez-Gil J.E. (2004). In vitro capacitation and acrosome reaction of dog spermatozoa can be feasibly attained in a defined medium without glucose. Reprod. Dom. Anim., 39:129-135.

AliW.A.H. and Mervat N. Ghazal (2013). In vivo and in vitro studies on the effect of Ganoderma on rabbit productivity, semen preservation and artificial insemination. J. of Animal and Poultry Prod., Mansoura Univ.,Vol.4 (12):715-731.

Ammar E. M., Said Sh. A. and Hassan M. S. (2004). Enhanced vasoconstriction and reduced vasorelazation induced by testosterone and nandrolone in hyper cholesterolemic rabbits. J. Pharmacology, 50(3):253-259.Book Series. G. U. Puplications, Abuja, Nigeria. 5-20.

Ceballos G., Figuroa L., Rubio I. and Gallo G. (1999).Acute and nongenomic effects of testosterone on isolated and perfused rat heart. J. Cardiovascular Pharmacology, 33:691-697.

Claude Kordon; I. Robinson; Jacques Hanoune; R. Dantzer (2012). Brain Somatic Cross-Talk and the Central Control of Metabolism. Springer Science \& Business Media. pp. 42- ISBN 978-3-642-189999. 
Dhinaa A.N. and Palanisamy P.K. (2010). Z-scan technique: to measure the total protein and albumin. J. of Biomedical Science and Engineering, (3):285-290.

Duncan, D.B. (1955). Multiple range and multiple F test.Biometrics, 11:142.

Du Plessis S.S., Agarwal A., Mohanty G. and vander Linde M. (2015). Oxidative phosphorylation versus glycolysis: What fuel do spermatozoa use. Asian J. of Andrology, 17:230-235.

Essig M., Maria G.V., Houten S., Landauer T., Gabica M. and Seifert A.L.(2007). Semen Analysis. Healthwitse.

Feldman B.F., Zinkl J.G. and Jain N.C. (2000). Schalm's Veterinary Hematology. $5^{\text {th }}$ Ed., Philadelphia, London.

Fredholm B.B. (2007). Adenosine, an endogenous distress signal, modulates tissue damage and repair. Cell Death Differ, 14(7):1315-1323.

Gogol P. (2013). Motility parameters and intracellular ATP content of rabbit spermatozoa stored for 3 days at 15o C. Folia Biol. (Kraków), 61:87-91.

Gogol P., Wierzchoś-Hilczer A. (2009). Membrane integrity, energy status and motility of rabbit spermatozoa stored for 2 days at $15^{\circ} \mathrm{C}$. Ann. Anim. Sci., 9:43-49.

Griffeth J. Richard, Bianad Vanessa and Nef Serge (2014). The emerging role of insulin-like growth factors in testis development and function. Basic and Clinical Andrology, 24:12

Gustavo F. (2001). Function of seminal vesicles and their role on male fertility. Asian J. Andeow, 3:251-258.

Hardi, D.G. (2003). The AmP activated protein kinas cascade: The key sensor of cellular energy. J. Endocrinology, 144:5179-5183.

Hsia C. C. W. (1998). Respiratory Function of Hemoglobin. J. Medicine, 338:239-247.

Jeyabalan, J., Shah M., Viollet B. and Chenu C. (2012).AmP activated protein kinase pathway and bone metabolism. J. Endocrinology, 212:277-290. Kraus.

Kara, F.M., Chitu, V., Sloane, J., Axelrod, M., Fredholm, B. B., Stanley, R. and Cronstein, B.N. (2010). Adenosine A1 receptors $\left(A 1 R_{S}\right)$ play a critical role in osteoclast formation and function. J. Faseb., 24(7): 2325-2333.

Katoh K., Komatsu T., Yonekura S., Ishiwata H., Hagino A. and Obara Y. (2001).Effects of adenosine 5-triphosphate and growth hormone on cellular $\mathrm{H}+$ transport and calcium ion concentrations in cloned bovine mammary epithelial cells. J. Endocrinology, 169:381-388. 
Kessler G. and Wolfman M. (1964). An automated procedure for simulataneous determination of calcium and phosphorus. J. Chemistry, 10:686.

Lebas F., Coudert P., de Rochambea H. and Thebault R.G. (1997). FAO Animal Production and Health Series No.21. The rabbit:husbandry, health and production. ISBN 92 - 5 - 103441-9.

Linden J. (2005). Adenosine in tissue protection and tissue regeneration. $J$. Mmolpharmacol., 67(5):1385-1387.

Mahmoud K.G.M, El-Sokary A.A.E., Abou El-Roos M.E.A., Abdel Ghaffar A.D. and Nawito M.(2013).Sperm Characteristics in Cryopreserved Buffalo Bull Semen and Field Fertility. Iranian J. of Applied Animal Science, 3(4):777-783.

Marchetti C., Jouy N., Leroy-Martin B., Defossez A., Formstecher P. and Marchetti P. (2004). Comparison of four fluorochromes for the detection of the inner mitochondrial membrane potential in human spermatozoa and their correlation with sperm motility. Hum. Reprod., 19:2267-2276.

MichaelW.K. (2012). Introduction to amino acid metabolism. J. Medical Biochemistry. 15(3):361-371.

Naughton C.K., Nelson D.R. and Thomal A.J. (2003). Development of an inexpensive artificial vagina for semen collection from rabbits. $J$. Androl., 34(5):712-715.

Okpanachi U., Aribido S.O. and Daikwo I.S. (2010). Growth and haematological response of growing rabbits to diets containing graded levels of sun dried bovine rumen content. African Journal of Food, Agriculture, Nutrition and Development, 10 (11):4444-4457.

Olayemi F.O. (2007). Evaluation of the reproductive and toxic effects of Cnestis ferruginea de Candolle) root extract in male rats. Ph.D Thesis. Dept. of Physiology, University of Ibadan. 26:263.

Pagat G.E. and Barnas J.H. (1964). Evaluation of drug activities. J. Pharmacometries, 1:456.

Quinterio-Moreno A., Rigaul T., Rodríguez-Gil JE. (2007). Multivariate cluster analysis regression procedures as tools to identify motile sperm subpopulations in rabbit semen and to predict semen fertility and litter size. Reprod. Dom. Anim.,42:312-319.

Rodriguez-Miranda E, Buffone MG, Edwards SE, Ord TS, Lin K, Sammel MD, Gerton GL, Moss SB and Williams CJ.(2008). Extracellular adenosine 5- triphosphate alters motility and improves the fertilizing capability of mouse sperm. Biol Reprod. , 79:164-171. 
SAS (1996): SAS Users Guide; Statistics. Ver. 6. 04, Fourth Edition, Sas Institute, Inc., Cary, NC.

Sonnenwrith A.C. and Jarette L. (1990). Gradwal's clinical laboratory. Method and diagnosis. $1^{\text {st }}$ ed. PP 258-259, C.V. Mosby Co., St. Louis, Toronto, London.

Thuwanut P., Arya N., Comizzoli P. and Chatdarong K. (2015). Effect of extracellular adenosine 5'-triphosphate on cryopreserved epididymal cat sperm intracellular ATP concentration, sperm quality, and in vitro fertilizing ability. Theriogenology, (5):702-05.003.

Thuwanut P. and Chatdarong K. (2011). Extracellular adenosine 5triphosphate (ATP): effects on cryopreserved epididymal cat sperm. $J$. Veterinary Medicine, 41:117-118.

Verma O P., Kumar R., Kumar A. and Chand S. (2012).Assisted Reproductive TechniquesinFarmAnimal-From Artificial Insemination to Nano Biotechnology. Vet. World, Vol. 5 (5):301-310.

William H.W. and Jing G. (2005). FSH and Testosterone signaling in sertoli cells. J. Reproduction and Fertility, 130:15-28.

Yujin Z., Yingbo D., Jiamming W., Weiru Z., Almut G., Hong S., Lijian T., Guang X., Danny C.A., Michael V.M., Dorothyl E.L. and Harinder S.J. (2010). Deterimental effects of adenosine signating in sickle cell disease. J. Nature Medicine, 17:79-86.

Zhang-Zhang Y.u, Jing Chen, Pei-Qin Shou and Lei Fang (2014).Effect of micronutrients on the reproduction of infertility rat model induced by adenine. Int. J. Clin. Exp. Med., 7(9):2754-2762.

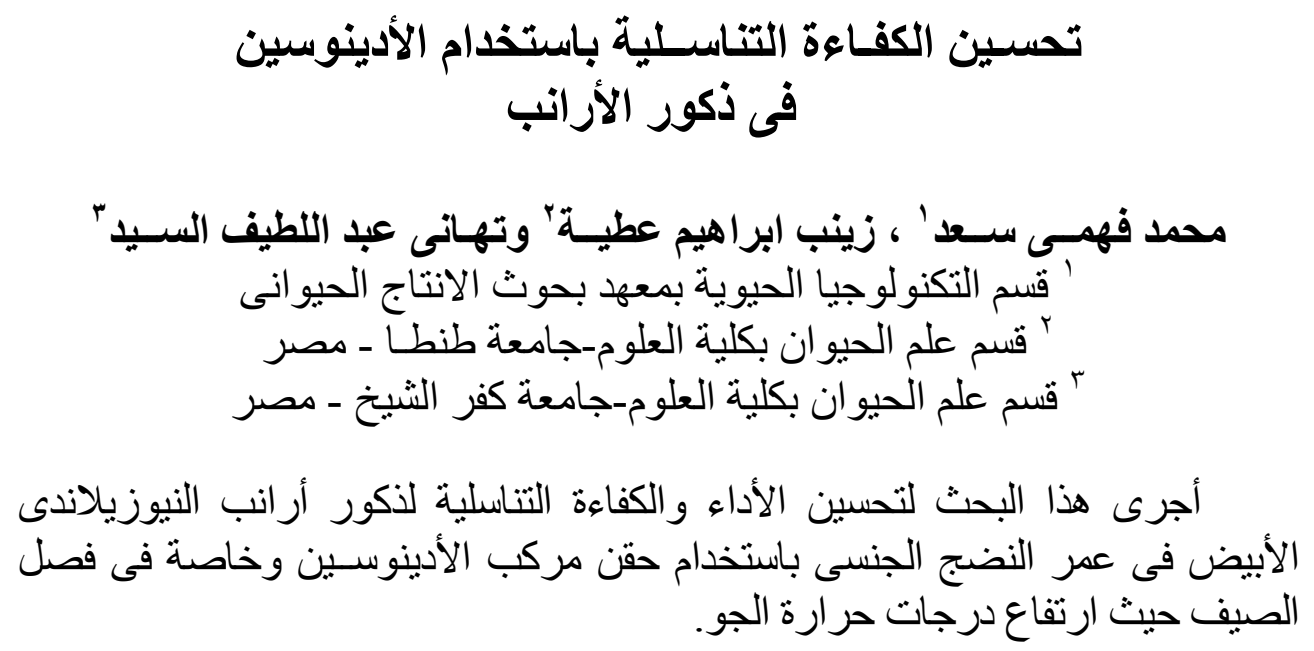


وكاتت الدراسة كالأتى: تم استخدام عدد ^ 1 ذكر من الأر انب النوزيلاندى الأبيض

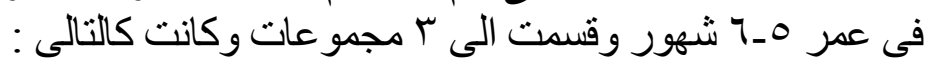
1 ـ المجموعة الأولى 7 ذكور من الأرانب لم يتم حقنه بأى شيء وكانه وتعتبر مجموعة ضابطة. r - المجموعة الثانية وهى 7 ذكور من الأرانب وتم حقنها بمركب الأدينوسين بتركيز

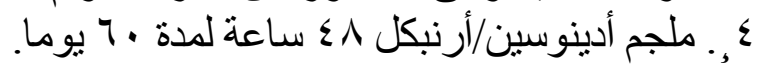

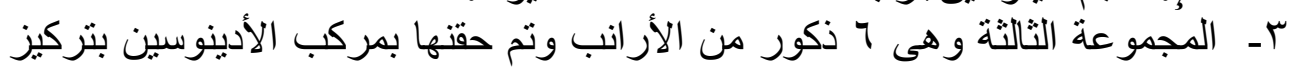

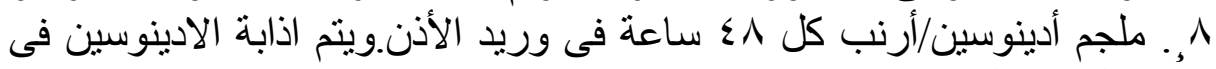

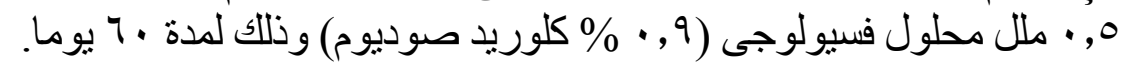

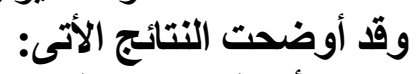

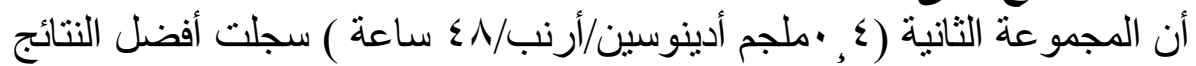

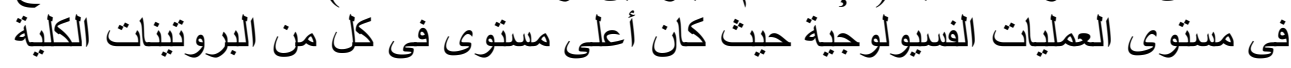

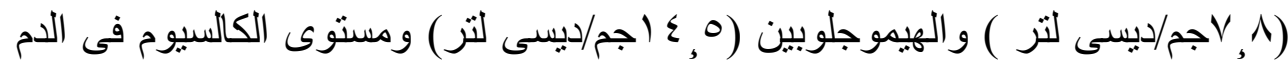

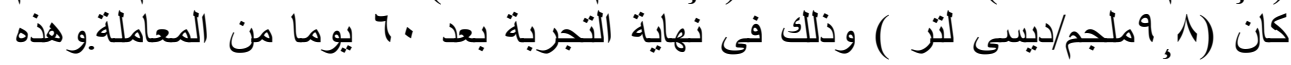

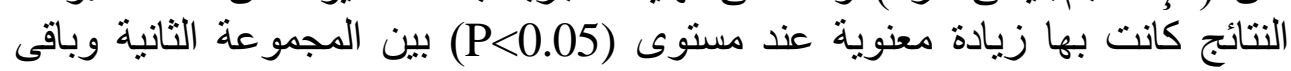
كما أنها (المجموعة الثانية) سجلت ارتفاعا معنويا فى مستوى نزكيز هرمون

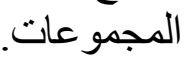

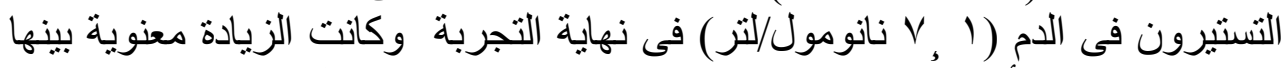

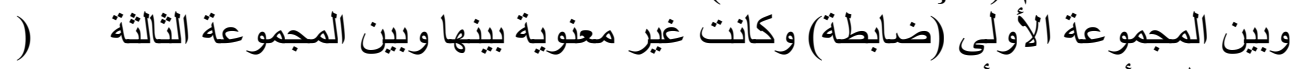
1 ، • ملجم أدينوسين/أرنب). كما أظهرت النتائج بالنسبة للصفات الطبيعية للسائل المنوى كالأتى: أن حيوانات

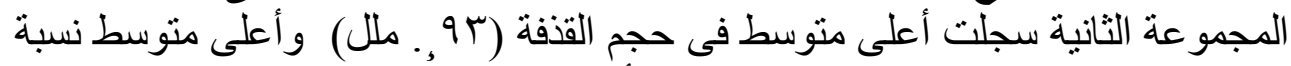
المئوية فى حيوية الاسبرمات (

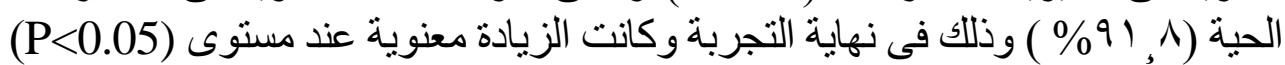

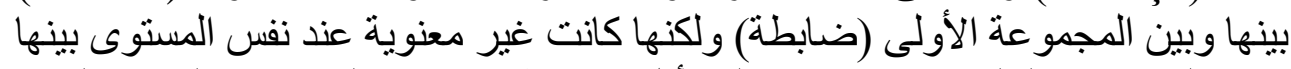

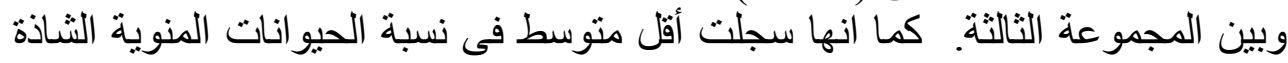

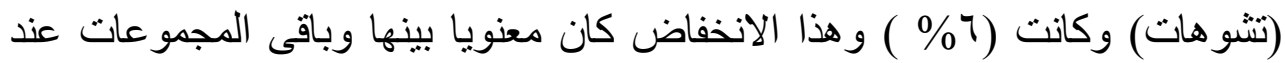

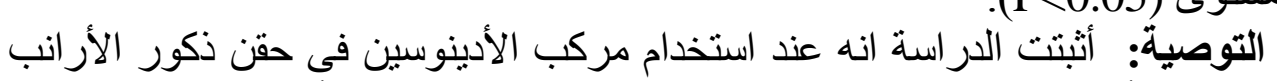

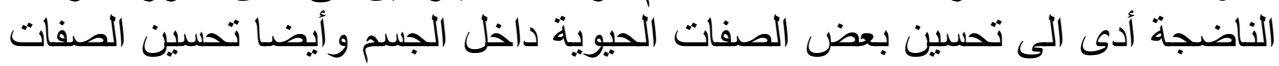

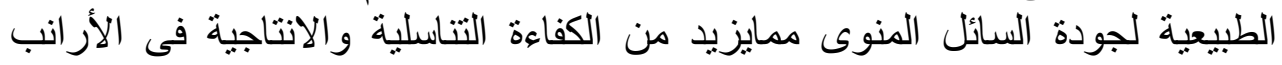

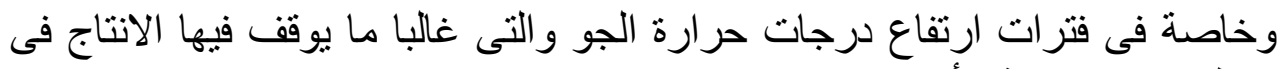
معظم مزارع تربية الأرانب. فئ. 